\title{
MOTIVASI KERJA PEGAWAI DALAM PELAYANAN PUBLIK DI SEKRETARIAT PEMERINTAH DAERAH KABUPATEN TAKALAR
}

\author{
Nurbiah Tahir \\ Dosen Administrasi Negara Fisipol Unismuh Makassar \\ Email : nurbiahtahir@gmail.com,nurbiahtahir@unismuh.ac.id
}

\begin{abstract}
ABSTRAK
Penelitian ini bertujuan untuk mengetahui tingkat motivasi kerja pegawai, tingkat pelayanan publik dan hubungan motivasi kerja pegawai dalam pelayanan publik di Sekretariat Pemerintah Daerah Kabupaten Takalar.Jenis Penelitian ini menggunakan pendekatankualitatif, dengan metode fenomenologi. Penelitian kualitatif dimaksudkan untuk mengeksplorasi dan memahami makna dari masalah-masalah sosial (Creswell, 2010). Fenomenologi yang dimaksud adalah peneliti berorientasi pada fenomenologis yang menekankan pada aspek subjektif dari tingkah laku manusia dengan melihat realitas sebagai konstruksi sosial, karena realitas juga merupakan hasil berbagi pengalaman berinteraksi antara satu orang dengan orang lain (Irawan, 2006). Hasil penelitian menunjukkan Tingkat motivasi kerja yang diberikan kepada para pegawai di Kantor Sekretariat Pemerintah Daerah Kabupaten Takalar masih masih perlu ditingkatkan, begitupula dengan pelayanan publik yang masih perlu perbaikan karena terlihat hubunganpositif dengan adanya motivasi kerja dalam pelayanan publik di Sekretariat Pemerintah Daerah kabupaten Takalar.
\end{abstract}

Kata Kunci: Motivasi Kerja, Pelayanan Publik

\section{PENDAHULUAN}

Motivasi dapat dikatakan sebagai faktor pendorong yang berasal dalam diri manusia yang akan mempengaruhi cara bertindak seseorang. Dengan demikian motivasi kerja akan berpengaruh terhadap ferformansi pekerja. Semua teori motivasi dikaitkan dengan pemuasan kebutuhan manusia (Siagian, 2002). Teori motivasi yang paling terkenal adalah teori Hirarki Kebutuhan oleh Abraham Maslow. Ia membuat hipotesis bahwa dalam setiap diri manusia terdapat hierarki dari lima kebutuhan, yaitu fisiologis (rasa lapar, haus, seksual, dan kebutuhan fisik lainnya), rasa aman (rasa ingin dilindungi dari bahaya fisik dan emosional), sosial (rasa kasih sayang, kepemilikan, penerimaan, dan persahabatan), penghargaan (faktor penghargaan internal dan eksternal), dan aktualisasi diri (pertumbuhan, pencapaian potensi seseorang, dan pemenuhan diri sendiri). Hal inilah yang mendorong manusia untuk memperbaiki ferforma kerja pegawai.

Dengan mengaitkan pula teori motivasi Douglas Mc Gregor menemukan teori $\mathrm{X}$ dan Y.Kedua faktor $\mathrm{X}$ dan $\mathrm{Y}$ inilah yang membutuhkan daya dorong untuk melakukan gerak guna membangun individu menjadi lebih baik, sehingga untuk menghadapi kedua faktor tersebut tentu akan membutuhkan tindakan yang berbeda pula, Asumsi pertama adalah bahwa para 
bawahan tidak menyenangi pekerjaan, pemalas, tidak senang memikul tanggung jawab, dan harus dipaksa agar menghasilkan sesuatu. Para bawahan yang diasumsikan berciri seperti itu dikategorikan sebagai manusia X. Dalam organisasi terdapat pula para karyawan yang senang bekerja, kreatif, menyenangi tanggung jawab, dan mampu mengendalikan diri, mereka dikategorikan sebagai manusia Y. Implikasinya terhadap motivasi pasti ada, para manejer akan lebih mungkin berhasil menggerakkan manusia $X$ jika menggunakan motivasi negatif, sedangkan menghadapi para bawahan yang termasuk kategori Y motivasi positiflah yang akan lebih efektif. Misalnya, upaya mendorong manusia X meningkatkan produktivitasnya adalah berupa imbalan disertai dengan ancaman bahwa jika yang bersangkutan tidak bekerja dengan lebih baik, kepadanya akan dikenakan sanksi organisasi. Sebaliknya, pujian atau penghargaan akan merupakan senjata yang ampuh untuk mendorong manusia $\mathrm{Y}$ meningkatkan kualitas kerjanya.

Berbicara masalah motivasi kerja, sangat erat hubungannya dengan performansi pekerjaan sebagaimana disebutkan sebelumnya, begitu pula keterkaitannya dengan pelayananan publik. Pelayanan publik di Indonesia masih sangat rendah (Pasolong, 2007), Dari segi kualitas, pelayanan publik kita memang bukan yang terburuk di ASEAN. Indonesia sedikit lebih baik dari Myanmar, Filipina, Laos, dan Kamboja. Namun, kita kalah jauh dari Singapura, Vietnam, dan Malaysia. Di tingkat global, pelayanan publik di Indonesia berada di peringkat 126 dari 180 negara yang diobservasi. Itu jelas bukan prestasi yang layak dibanggakan (republika, 2016).

Buruknya pelayanan publik di Indonesia bukan semata-mata disebabkan oleh mentalitas para aparatur pelaksana birokrasi di lapisan bawah saja. Tetapi, juga karena masalah mentalitas para pejabat negara, mulai dari menteri, dirjen (direktur jenderal), direktur, gubernur, bupati wali kota, sekda (sekretaris daerah), hingga kepala-kepala dinas. Karena, merekalah sesungguhnya yang bertanggung jawab membuat prosedur operasi standar (SOP) pelayanan publik.

Sayangnya, dalam membuat SOP tersebut, para pejabat itu cenderung tidak mengimplementasikan UU No. 25 Tahun 2009 (tentang Pelayanan Publik) dengan baik. Selama lima tahun terakhir, Ombudsman RI menemukan bahwa kepatuhan penyelenggara pelayanan publik terhadap UU tersebut memang sangat rendah, yakni hanya berkisar 18-20 persen. Jadi, sumber utama masalahnya terletak pada sistem yang diterapkan secara keliru. Jika kemudian banyak masyarakat yang mengeluhkan pelayanan publik kita jelek, itu tak lain disebabkan oleh pengabaian para pejabat negara dalam mengimplementasikan UU No. 25 tahun 2009. Karena, bagaimanapun, para pelaksana birokrasi itu hanya menjalankan sistem yang dibuat oleh pejabat yang menjadi atasan mereka.

Dalam Governance and Desentralization disingkat GDS 2002 menemukan tiga masalah penting yang banyak terjadi di lapangan dalam penyelenggaraan pelayanan publik, yaitu pertama, besarnya diskriminasi pelayanan. Penyelenggaraan pelayanan masih amat dipengaruhi oleh hubungan per-konco-an, kesamaan afiliasi politik, etnis, dan agama. Fenomena semacam ini tetap marak walaupun telah diberlakukan UU No. 25 Tahun 2009tentang Penyelenggaraan Negara yang Bersih dari KKN yang secara tegas menyatakan keharusan adanya kesamaan pelayanan, bukannya diskriminasi. Kedua, tidak adanya kepastian biaya dan waktu pelayanan. Ketidakpastian ini sering menjadi penyebab munculnya $\mathrm{KKN}$, sebab para pengguna jasa 
Nurbiah Tahir, Motivasi Kerja Pegawai Dalam Pelayanan Publik Di Sekretariat Pemerintah Daerah Kabupaten

Takalar $\mid 3$

cenderung memilih menyogok dengan biaya tinggi kepada penyelenggara pelayanan untuk mendapatkan kepastian dan kualitas pelayanan. Dan ketiga, rendahnya tingkat kepuasan masyarakat terhadap pelayanan publik. Ini merupakan konsekuensi logis dari adanya diskriminasi pelayanan dan ketidakpastian tadi. publik dalam konteks kekinian ditafsirkan menjadi masyarakat umum (Sinambela, 2008).

Melihat fenomena di atas penting adanya motivasi yang diberikan kepada bawahan guna membantu dalam meningkatkan kinerja, dengan menyesuaikan motivasi apa yang perlu dan dibutuhkan oleh para bawahan.

\section{KAJIAN TEORI}

\section{Teori Motivasi}

Motivasi dapat diartikan sebagai faktor pendorong yang berasal dalam diri manusia, yang akan mempengaruhi cara bertindak seseorang. Keberadaan Motivasi penting karena dengan motivasi ini diharapkan setiap individu karyawan mau bekerja keras dan antusias untuk mencapai produktivitas kerja yang tinggi (Hasibuan 2008). Adanya motivasi yang kuat dari seorang pegawai merupakan langkah awal dalam penyelesaian suatu pekerjaan dan tindakan. Karena motivasi itu sendiri merupakan kegiatan yang memberikan dorongan kepada seseorang atau diri sendiri untuk berbuat sesuatu tindakan yang dikehendaki. Sejalan dengan Gibson (2002) bahwa motivasi adalah suatu konsep yang kita gunakan jika kita menguraikan kekuatankekuatan yang bekerja terhadap atau di dalam diri individu untuk memulai dan mengarahkan perilaku. Motivasi bukanlah sesuatu yang dapat diamati, tetapi merupakan hal yang dapat disimpulkan adanya karena sesuatu perilaku yang tampak. Motivasi merupakan masalah yang kompleks dalam organisasi karena kebutuhan dan keinginan setiap anggota organisasi adalah berbeda-beda. Dan berkembang atas dasar proses belajar yang berbeda pula. Motivasi dapat ditimbulkan baik oleh faktor internalmaupun eksternal tergantung dari mana suatu kegiatan dimulai.

Dari beberapa teori motivasi yang telah dijelaskan sebelumnya yang dijadikan indikator pendukung dalam melakukan penelitian ini adalah teori motivasi menurut Frederick Herzberg dalam Siagian (2002) dan Hasibuan (2008) yang disebutnya sebagai “ Teori Motivasi dan Higiene" (Motivation-Hygiene Theory). Herzberg (Hasibuan, 2008) memandang bahwa kepuasan kerja berasal dari keberadaan motivator intrinsik dan bahwa ketidakpuasan kerja berasal dari ketidakberadaan faktor-faktor ekstrinsik. Faktor-faktor ekstrinsik (konteks pekerjaan) meliputi: (1) Upah, (2) Kondisi kerja, (3) Keamanan kerja, (4) Status, (5) Mutu hubungan interpersonal antar sesama rekan kerja, atasan, dan bawahan.

Keberadaan kondisi-kondisi ini terhadap kepuasan karyawan tidak selalu memotivasi mereka, tetapi ketidakberadaannya menyebabkan ketidakpuasan bagi karyawan, kondisi ekstrinsik disebut ketidakpuasan, atau faktor Hygiene. Faktor Intrinsik meliputi: (1) Pencapaian prestasi, (2) Pengakuan, (3) Tanggung Jawab, (4) Ketekunan Kerja, (5) Kemungkinan berkembang. Penggolongan motivasi seseorang dapat pula dilihat dari kebutuhan dan keinginan seseorang yang berbeda-beda pula. Penerapan motivasi diharapkan dapat meningkatkan kualitas 
4|Ad'ministrare, Vol. 3 No. 2, 2016

pelayanan publik, pada dasarnya setiap manusia membutuhkan pelayanan, bahkan secara ekstrim dapat dikatakan pelayanan tidak dapat dipisahkan dengan kehidupan manusia. Masyarakat setiap waktu selalu menutut pelayanan publik yang berkualitas dari birokrat, meskipun tuntutan tersebut sering tidak sesuai dengan harapan karena secara empiris pelayanan publik yang terjadi selama ini masih kurang memuaskan, berbelit-belit, lambat, mahal, dan melelahkan.

\section{Konsep Pelayanan Publik}

Kurniawan (2009) mengemukakan pelayanan publik diartikan, sebagai pemberian layanan (melayani) keperluan orang atau masyarakat yang mempunyai kepentingan pada organisasi itu sesuai dengan aturan pokok dan tata cara yang telah ditetapkan. Dalam pelayanan publik ada lima dimensi menurut Love Lock (Lukman, 2000) yang perlu diperhatikan yaitu: (1) Reliability yang ditandai pem-berian pelayanan yang tepat dan benar (keterjangkauan). (2) Tangibles yang ditandai dengan penyediaan yang memadai sumber daya manusia dan sumber daya lainnya.(3) Responsiveness yang ditandai dengan keinginan melayani konsumen dengan cepat (per-tanggungjawaban). (4) Assurance yang ditandai tingkat perhatian terhadap etika dan moral dalam memberikan pelayanan (jaminan). (5) Empaty yang ditandai tingkat kemauan untuk mengetahui keinginan dan kebutuhan konsumen.

Pentingnya pelayanan publik dapat dilihat dari perspektif pelayanan publik yang dikemukakan oleh Denhardt dan Denhardt sebagaimana dikutip oleh Mahsyar (2011) bahwa sekarang ini telah terjadi pergeseran paradigma dalam administrasi publik yakni new public service, paradigma ini menjelaskan bahwa administrasi publik harus me-layani warga masyarakat bukan pe-langgan, mengutamakan kepentingan publik dan melayani daripada mengen-dalikan. Berdasarkan perspektif tersebut, maka konsekuensinya adalah aparat sipil negara harus memiliki motivasi tinggi untuk memberikan pelayanan publik. Dengan adanya bentuk motivasi kerja pegawai dan didukung pula dengan indikator pelayanan publik, maka dapat diketahuai sejauah mana motivasi kerja memberikan dampak terhadap pelayanan publik khususnya di Kantor Sekretariat Pemerintah Daerah Kabupaten Takalar.

\section{METODE PENELITIAN}

Penelitian ini berlokasi di Kabupaten Takalar dengan mengambil obyek penelitian pada kantor Sekretariat PEMDA Kabupaten Takalar, Penelitian kualitatif dimaksudkan untuk mengeksplorasi dan memahami makna dari masalah-masalah sosial (Creswell, 2010:4). Fenomenologi yang dimaksud adalah peneliti berorientasi pada fenomenologis yang menekankan pada aspek subjektif dari tingkah laku manusia dengan melihat realitas sebagai konstruksi sosial, karena realitas juga merupakan hasil berbagi pengalaman berinteraksi antara satu orang dengan orang lain (Irawan, 2006:13). Teknik penentuan informan dilakukan dengan purposive sampling melalui key person, dengan menentukan kelompok peserta yang menjadi informan sesuai dengan kriteria terpilih yang relevan dengan masalah penelitian (Bungin, 2007:107). Penentuan informan kunci ditetapkan saat memasuki lapangan dan selama penelitian berlangsung atau dikenal dengan desain emergent sampling karena sampel atau informan dalam 
Nurbiah Tahir, Motivasi Kerja Pegawai Dalam Pelayanan Publik Di Sekretariat Pemerintah Daerah Kabupaten

Takalar $\mid 5$

penelitian kualitatif tidak dapat ditentukan sebelumnya (Sugiyono, 2009:219). Untuk memudahkan penentuan informan di lapangan, peneliti menargetkan informan kuncinya adalah pegawai pada kantor Kantor Sekretariat Pemerintah Daerah Kabupaten Takalar yang terlibat langsung dalam memberikan pelayanan ke pada Masyarakat, dan bagain-bagian penting dalam kantor tersebut yang dapat memberikan informasi yang dibutuhkan oleh peneliti, serta beberapa masyarakat yang dapat memberikan informasi sebagai dampak dari proses penelitian yang terjadi.

\section{HASIL DAN PEMBAHASAN}

Terkait dengan tingkat motivasi kerja pegawai pada Kantor Sekretariat Pemerntah Daerah Kabuaten Takalar, dilakukan dengan melihat indikator motivasi yang diberikan yaitu adanya faktor intrinsik dan ekstrinsik bagi para pegawai dalam meningkakan kinerjanya, disebutnya sebagai "Teori Motivasi dan Higiene (Motivation-Hygiene Theory)".

\section{Tingkat Motivasi Kerja}

Faktor Intrinsik meliputi: (1) Pencapaian prestasi. Tingkat keinginan pegawai untuk berprestasi sangat tinggi khususnya dalam memberikan pelayanan publik, sebagaimana pegawai disekretariat pemerintah daerah Kabupaten Takalar, akan tetapi bagi mereka tidak cukup dengan prestasi akan tetapi harus ada penghargaan terhadap prestasi yang mereka capai sehingga menjadi semangat bagi mereka yang berprestasi dan mendorong yang lain untuk ikut meningatkan kinerjanya; (2) Pengakuan. Terkait dengan pencapaian prestasi maka pengharagaan yang dimaksud oleh para pegawai tersebut adalah adanya pengakuan dari seorang atasan kepada para pegawaianya terhadap prestasi kerja yang mereka berikan dalam bentuk reward atau penghargaan. Pegawai di sekretariat pemerintah daerah Kabupaten Takalar mengemukaan bahwa Pengakuan dapat diberikan sebagai suatu bentuk perhatian dan kepercayaan yang diperoleh dari pimpinan maupun rekan kerja sendiri. Misalnya pengakuan dari pimpinan karena tugas yang diberikan dapat dikerjakan dengan baik yang dapat diikuti pula dengan pemberian penghargaan yang dapat berupa bonus atau pujian dari atasan sebagai akibat dari keberhasilan yang dicapai dalam menyelesaikan suatu pekerjaan; (3) Tanggung Jawab. Tanggung jawab berkenaan dengan beban kerja yang diberikan kepada pegawai karena adanya kepercayaan yang diberikan ke padanya, serta merupakan kesanggupan menerima pelimpahan wewenang dari seorang pimpinan,Pegawai Sekretariat Pemerintah Daerah Kabupaten Takalarmengemukakan bahwa semangat kerja pegawai ditentukan pula oleh tanggung jawab pekerjaan yang diberikan ke padanya, dalam hal ini pegawai masih banyak yang merasa tanggung jawab pekerjaan yang dibebankan ke padanya tidak sesuai dengan yang diharapkan sehingga menurunkan semangat kerja; (4) Ketekunan Kerja. pegawai setuju jika dikatakan mereka termotivasi memberikan pelayanan ke pada publik karena mereka memang menekuni pekerjaan tersebut dan mereka kurang setuju bahka tidak setuju jika dikatakan bahwa menekuni suatu pekerjaan bukan merupakan salah satu alat motivasi mereka dalam bekerja khususnya dalam melayani publik; (5) Kemungkinan berkembang.Kemungkinan berkembang yang dimaksud adalah suatu kondisi yang diharapkan terjadi perubahan dan perkembangan sesuai 
6|Ad'ministrare, Vol. 3 No. 2, 2016

dengan apa yang diharapkan baik kepada diri sendiri maupun pekerjaan yang dijalani, serta merupakan kemajuan yang dicapai oleh seorang pegawai yang mengarah pada pengembangan karir serta kematangan pribadi, mereka setuju jika dikatakan bahwa adanya suatu peluang untuk berkembang baik pada pekerjaan yang ditekuni maupun pada diri sendiri karena pekerjaan tersebut akan memotivasi seseorang untuk giat bekerja dengan harapan bahwa apa yang dikerjakannya selama ini tidak akan sia-sia dan akan memberikan hasil yang tidak mengecewakanbagiyang bersangkutan dan sebaliknya mereka akan kurang setuju bahkan tidak setuju jika hal tersebut dikatakan bukan merupakan suatu hal yang dapat memotivasi mereka dalam bekerja.

Dengan melihat pengaruh faktor intrinsik dalam memotivasi pegawai, maka penting juga diperhatikan Faktor-faktor ekstrinsik (konteks pekerjaan) yang meliputi: (1) Upah. Upah yang dimaksud adalah suatu bentuk imbalan yang diterima baik secara materil maupun non-materil oleh seorang pegawai karena pekerjaannya atau dari hasil kerja mereka.Pemberian upah kepada pegawai dimaksudkan untuk merangsang kerja pegawai dalam menyelesaikan tugas-tugas yang dibebankan ke padanya atau sebagai salah satu alat motivasi yang dapat meningkatkan hasil kerjanya, karena terkadang insenif yang positif tidak memuaskan. Beban kerja yang diberikan tidak seimbang dengan upah yang diberikan, hal ini sering menurunkan pula semangat kerja. Akan tetapi pegawai tidak terlalu termotivasi dengan upah ataupun gaji yang diberikan dan hanya sebagian kecil yang setuju bahkan sangat setuju dengan pernyataan tersebut serta menunjukkan pula bahwa tidak selamanya pemberian upah ataupun gaji ke pada para pegawai dapat memberikan motivasi untuk bekerja lebih baik dari sebelumnya. Dengan melihat hal tersebut penting sekali memperhatikan keberadaan antara faktor $\mathrm{X}$ dan $\mathrm{Y}$ dalam memberikan motivasi kepada para pegawai; (2) Kondisi kerja. Kondisi kerja yang dimaksud adalah situasi yang terjadi dalam lingkungan kerja atau segala sesuatu yang ada di sekitar pegawai yang dapat mempengaruhi kerja mereka. Termasuk kondisi ruangan, kebersihan ruangan, ventilasi, ruang kerja yang cukup luas, dan lain-lain yang turut membantu memotivasi pegawai dalam bekerja.Kondisi kerja sangat memberikan pengaruh yang positif terhadap pegawai dalam bekerja dimana sebagian besar pegawai mengatakan setuju yang artinya kondisi kerja dapat memotivasi mereka untuk bekerja melayani publik dengan baik dan kondisi kerja sangat menunjang segala aktivitas pegawai dalam bekerja khususnya dalam melayani publik; (3) Keamanan kerja. Keamanan kerja yang dimaksud adalah suatu kondisi yang nyaman dan aman dalam bekerja sehingga memotivasi pegawai dalam bekerja melayani publik. Keamanan kerja yang dimaksud adalah keamanan kerja yang berkaitan dengan kondisi fisik seorang pegawai dalam bekerja, baik dari segi keamanan penjagaan lingkungan kantor maupun dari keamanan penggunaan alat-alat kantor yang merupakan alat yang selalu dipergunakan pegawai setiap harinya dalam bekerja.Sebagian besar pegawai memang sangat termotivasi untuk bekerja karena keamanan tempat mereka bekerja sangat terjamin yang memudahkan mereka untuk beraktivitas melakukan tugas dan fungsinya masing-masing, keamanan kerja yang diberikan pada suatu instansi atau tempat kerja manapun memang sangat dibutuhkan oleh para peagawai dan hal ini merupakan suatu bentuk perhatian oleh pimpinan ke pada para pegawainya; (4) Status. Status dapat diartikan sebagai penggambaran terhadap kondisi pribadi seseorang dalam masyarakat (status pernikahan), yang dapat memberikan motivasi kerja yang lebih karena status yang 
Nurbiah Tahir, Motivasi Kerja Pegawai Dalam Pelayanan Publik Di Sekretariat Pemerintah Daerah Kabupaten

Takalar $\mid 7$

dimilikinya, status seseorang sangat mempengaruhi dan memotivasi seseorang untuk lebih giat dan lebih baik lagi dari sebelumnya karena mereka merasa di luar dari pekerjaan yang ditekuninya merekapun mempunyai tanggungjawab yang cukup besar dalam keluarganya sehingga banyak pegawai yang memberikan jawaban setuju atas pernyataan tersebut, akan tetapi banyak pula pegawai yang memberikan jawaban yang kurang setuju jika dikatakan bahwa status merupakan salah satu alat motivasi diri untuk bekerja lebih baik dalam melayani publik, dan ini menunjukkan pula bahwa status setiap pegawai atau kondisi pribadi setiap orang itu berbedabeda; (5) Hubungan Interpersonal. Hubungan interpersonal ini dimaksudkan adalah segala bentuk pola hubungan yang terjadi, baik antar pegawai dengan atasannya maupun di antara pegawai itu sendiri. Hubungan dengan atasan menyangkut tentang segala bentuk pola hubungan yang terjadi melalui interaksi, khususnya yang berkaitan dengan pelaksanaan tugas-tugas rutin di kantor. Hubungan antar pegawai menyangkut semua aspek pola hubungan yang terjadi sesama rekan kerja.Secara psikologis hubungan yang terjadi tersebut sangat memberikan pengaruh yang besar terhadap gairah dan semangat kerja yang pada akhirnya dapat meningkatkan kelancaran pelaksanaan tugas sehari-hari, sebab salah satu alat penunjang suksesnya suatu pekerjaan adalah tingkat komunikasi yang baik. Banyanya pegawai setuju mengenai hubungan interpersonal yang terjalin dengan baik antar sesama rekan kerja maupun ke pada atasan atau pimpinan karena hubungan interpersonal merupakan hal yang penting dalam bekerja dan bukan hanya sabagai salah satu alat yang dapat memotivasi seseorang untuk bekerja, akan tetapi hubungan interpersonal dalam bekerja memang sangat dibutuhkan demi terciptanya suasana kerja yang nyaman.

\section{Tingkat Pelayanan Publik}

Selain tingkat motivasi, penting juga mengetahui tingkat pelayanan publik yang diberikan kepada masyarakat dengan mengacu pada indikator pelayanan publik yang meliputi: (1) Reliability yang ditandai pemberian pelayanan yang tepat dan benar (keterjangkauan). Tanggapan para masyarakat masih menganggap bahwa pelayanan pemerintah terhadap masyarakat masih butuh pembenahan, sehingga tepat dan benar dalam pelayanannya; (2) Tangibles yang ditandai dengan penyediaan yang memadai sumber daya manusia dan sumber daya lainnya. sebagian besar masyarakat setuju jika dikatakan bahwa mereka termotivasi mendapatkan pelayanan publik karena mereka merasa ada keseimbangan yang terjadi baik pada sumber daya manusianya maupun pada sumber daya lainnya yang digunakan dalam kegiatan melayani publik sehingga berdampak pada hasil kerja mereka, hal ini berkenaan dengan kompetensi aparatur, yang menunjukkan pula bahwa kondisi kantor pemerintah dalam melayani publik masih dalam tahap stabil; (3) Responsiveness yang ditandai dengan keinginan melayani konsumen dengan cepat (pertanggungjawaban), kegiatan yang tidak menyita waktu juga dapat menunjang kualitas pelayanan ke pada masyarakat dan dapat memberikan kesan yang baik oleh masyarakat ke pada pemerintah sebagai pelayan publik. Masih banyak masyarakat merespon rendah terhadap pelayanan yang diberikan pemerintah kepadanya, sehingga ini menjadi pekerjaan rumah yang penting bagi pemerintah untuk dibenahi; (4) Assurance yang ditandai tingkat perhatian terhadap etika dan moral dalam memberikan pelayanan (jaminan).Masyarakat 
8|Ad'ministrare, Vol. 3 No. 2, 2016

masih menganggap pelayanan yang diberikan pemerintah ke padanya masih kurang adil menurut mereka, masih adanya diskriminasi terhadap pelayanan publik yang membuat mereka belum merasakan kepuasan dalam hal pelayanan pemerintah; (5) Empaty yang ditandai tingkat kemauan untuk mengetahui keinginan dan kebutuhan konsumen.Hal ini menunjukkan sikap profesional dalam melayani masyarakat selain berupa pendekatan fisik juga dibutuhkan hubungan kekeluargaan ke pada masyarakat sebagai konsumen yang dilayani. Sebagian masyarakat masih menganggap bahwa pelayanan yang diberikan pemerintah kepadanya masih kurang profesional, hal ini berkenaan dengan kompetensi sumber daya yang dimiliki, dimana kompetensi aparatur sangat mendukung pula profesionalisme kerja para aparatur daerah yang berefek terhadap pelayanan publik.

\section{Hubungan Motivasi Kerja dengan Pelayanan Publik}

Untuk mendapatkan hasil pekerjaan yang baik dari seorang bawahan atau pegawai, maka tidak lepas dari bagaimana seorang pimpinan memotivasi para bawahannya. Selain motivasi yang terjadi antara pimpinan dengan bawahan, motivasi antar rekan kerja atau sesama pegawai juga dapat dilakukan, ini bertujuan agar tercipta suasana kerja yang lebih kekeluargaan dan menyenangkan dan yang tidak kalah penting tidak membosankan.

Berdasarkan hasil wawancara yang penulis lakukan terhadap informan maupun responden serta pengamatan langsung di lapangan, maka dapat diketahui hubungan motivasi kerja dengan pelayanan publik, adalah :(1) Motivasi kerja yang diberikan oleh pimpinan ke pada karyawan sangat membantu dalam menyukseskan kegiatan ataupun pekerjaan yang hendak dilakukan, sebab motivasi tersebut dapat memberikan semangat kerja yang lebih dibanding tanpa adanya dorongan atau motivasi langsung ke pada karyawan; (2) Motivasi kerja juga tidak selamanya berupa benda atau barang-barang yang dapat dihitung nilainya, akan tetapi motivasi yang langsung memberikan semangat dan dorongan juga sangat membantu karyawan dalam melaksanakan tugasnya sebagai pelayan publik; (3) Faktor ekstrinsik dan intrinsik dalam memotivasi karyawan sangat dibutuhkan karena ke dua faktor tersebut dapat mewakili kebutuhan karyawan atau pegawai pada umumnya.

Dalam penelitian ini, ditemukan pula bahwa tidak selamanya motivasi dapat meningkatkan semangat kerja dalam melakukan pelayanan ke pada masyarakat, jika dikaitkan dengan faktor ekstrinsik dan intrinsik dalam memotivasi karyawan. Tidak semua motivasi tersebut dapat meningkatkan semangat melayani publik ataupun meningkatkan kualitas pelayanan ke pada publik. sebab kebutuhan dan keinginan setiap orang berbeda-beda.

Untuk lebih jelas melihat hubungan motivasi kerja dengan pelayanan publik, dalam hal ini penulis memfokuskan pada faktor ekstrinsik yang banyak mendapatkan tanggapan dari para responden maupun informan. (1) Upah, tidak selamanya upah yang diberikan mendorong semangat kerja yang lebih disbanding sebelumnya, walaupun pada dasarnya manusia butuh uang, Kondisi kerja, keadaan yang mendukung saat melakukan pekerjaan tidak lepas kondisi kerja yang memadai, akan tetapi hal tersebut hanya sebagian kecil dari hal-hal yang dapat memotivasi seseorang unutuk meningkatkan kinerjanya dalam melayani publik; (2) Keamanan kerja, walaupun keamanan kerja merupakan faktor pendorong tetapi hal tersebut tidak berbeda 
Nurbiah Tahir, Motivasi Kerja Pegawai Dalam Pelayanan Publik Di Sekretariat Pemerintah Daerah Kabupaten

Takalar $\mathbf{9}$

jauh dengan kondisi kerja; (3) Status (status pernikahan), hal ini juga tidak berbeda jauh dengan faktor ekstrinsik sebelumnya, akan tetapi keadaan ini lebih mendorong seseorang untuk lebih giat dan rajin lagi bekerja sebab mereka memiliki tanggung jawab di luar dari pekerjaan yang dijalaninya sekarang; (4) Hubungan Interpersonal, hal ini merupakan hal penting dan pendorong semangat kerja dalam melayani publik karena kenyamanan bersosialisasi jauh lebih penting dibanding yang lain.

Tanggapan lain dapat dilihat mengenai ke lima indikator pelayanan publik (Lukman, 2000) dalam hubungannya dengan pelayanan publik.

Masyarakat sebagai konsumen yang dilayani masih merasa pelayanan yang diberikan ke padanya belum bisa dikatakan tepat dan benar mengingat mereka masih belum bisa mendapatkan pelayanan yang sesuai dengan keinginan dan kebutuhan mereka, Masyarakat masih menganggap pelayanan publik yang diberikan ke padanya masih belum memenuhi standar walaupun sebagian masyarakat juga sudah menganggap pelayanan yang diberikan sudah memenuhi standar. Karena pada umumnya masyarakat belum memahami betul bagaiman standar atau indikator dalam pelayanan publik, Masyarakat masih menginginkan dilakukan peningkatan kinerja dalam hal melayani publik agar apa yang mereka harapkan bisa tercapai, kondisi yang sering mereka alami adalah banyaknya waktu yang tersita hanya untuk melayani satu permintaan masyarakat serta pelayanan yang mereka anggap belum adil.

\section{SIMPULAN}

Berdasarkan hasil penelitian dapat disimpulkan bahwa : (1) Tingkat motivasi kerja yang diberikan kepada para pegawai di Kantor Sekretariat Pemerintah Daerah Kabupaten Takalar masih perlu ditingkatkan; (2) Kemampuan memberikan pelayanan ke pada publik atau masyarakat masih kurang dirasakan manfaatnya oleh masyarakat yang mengakibatkan masih rendahnya tingkat pelayanan publik yang dilakukan oleh para pegawai dalam menjalankan tugasnya, (3) Ada hubungan yang positif dengan adanya motivasi kerja dalam pelayanan publik.

\section{DAFTAR PUSTAKA}

Boediono, 2003. Pelayanan Prima Perpajakan. Jakarta: Rineka Cipta.

Creswell, W.J. 2010. Reseach Design Qualitative and Quantitative Approach. Penerjemah Achmad Fawaid. Yogyakarta: Pustaka Pelajar.

Gibson, dkk. 2002. Organisasi: Perilaku, Struktur dan Proses. Jakarta: Erlangga.

Hasibuan, Malayu, S.P. 2008. Organisasi dan Motivasi. Jakarta: Bumi Aksara.

Irawan, Prasetya. 2006. Penelitian Kualitatif dan Kuantitatif untuk Ilmu-ilmu Sosial. Jakarta: Departemen Ilmu Administrasi FISIPOL UI.

Kurniawan, Agung. 2005. Transformasi PelayananPublik. Yogyakarta: Pembaruan.

Lukman, Sampara. 2000. Manajemen Kualitas Pelayanan. Jakarta: STIA LAN Press.

Mahsyar, Abdul. "Masalah Pelayanan Publik di Indonesia dalam Perspektif Administrasi

Publik." OTORITAS: Jurnal Ilmu Pemerintahan 1.2 (2011): 81-90.

Pasolong, Harbani. 2007. Teori Administrasi Publik. Bandung: Alfabeta. 
10|Ad'ministrare, Vol. 3 No. 2, 2016

Siagian, Sondang P.2002. Kiat Meningkatkan Produktivitas Kerja. Jakarta : Rineka Cipta. Sinambela. L.P. 2008. Reformasi Pelayanan Publik.Jakarta : Bumi Aksara.

http://www.republika.co.id/berita/koran/bincang-bisnis/14/12/16/ngny4a19-dananggirindrawardana-ketua-ombudsman-ri-pelayanan-publik-belum-membanggakan, diakses pada Senin, 18 Juli 2016.

UU Nomor 25 Tahun 2009. Tentang Pelayanan Publik 